\title{
Spiritual Distress in Cancer Patients: A Synthesis of Qualitative Studies
}

\author{
Helga Martins ${ }^{1}(\mathbb{D})$ and Sílvia Caldeira ${ }^{2, * \mathbb{D}}$ \\ 1 Institute of Health Sciences, Universidade Católica Portuguesa, 1649-023 Lisbon, Portugal; \\ helga.t.martins@gmail.com \\ 2 Researcher at the Centre for Interdisciplinary Research in Health, Institute of Health Sciences, \\ Universidade Católica Portuguesa, Palma de Cima, 1649-023 Lisbon, Portugal \\ * Correspondence: scaldeira@ics.lisboa.ucp.pt
}

Received: 21 August 2018; Accepted: 18 September 2018; Published: 20 September 2018

\begin{abstract}
Cancer affects individuals in all human dimensions. Cancer patients are more susceptible to spiritual distress. Several studies have addressed spiritual distress using quantitative designs; however, a qualitative approach to the experience of spiritual distress could provide a deeper understanding of the phenomenon. This study aims to synthesis the experience of spiritual distress as lived by cancer patients in qualitative primary studies. This is a literature review based on electronic databases search. A total of 4075 citations was identified and 23 studies were included. The most frequent qualitative research method was phenomenology $(n=15)$, and interviews were the main data collection method $(n=20)$. Two major themes have been identified related to the experience of spiritual distress: suffering and coping. Spiritual distress is an intimate, deep and suffering experience in life, which requires coping strategies and involves spiritual values and beliefs. Healthcare providers should be aware of this experience and recognize spiritual distress in cancer patients, as it is critical in providing holistic nursing care.
\end{abstract}

Keywords: cancer patients; nursing; qualitative studies; spiritual distress

\section{Introduction}

Cancer leaves an alarming and devastating effect at the global level and is considered a leading public health problem (Siegel et al. 2018). Cancer is one of the world's leading causes of morbidity and mortality, with 14 million new cases and eight million cancer-related deaths have been diagnosed in 2012 (WHO 2014). In the USA, 4700 new cases of cancer are diagnosed each day (Siegel et al. 2018), $87 \%$ of all cancers are diagnosed in patients having 50 years of age or older, and the mortality rate is 1670 deaths per day, resulting in the second leading cause of death (American Cancer Society 2018). The burden of having cancer is a worldwide reality, but main cancers can be avoided, and the focal key word to fight cancer is prevention through tobacco control, vaccination, early detection, and promotion of healthy lifestyles (Torre et al. 2016). Cancer has a nefarious effect on patients' life and can decrease hope and dreams (Villagomeza 2005). The diagnosis of cancer originates the most alarming response, as compared to other diagnosis (Sawyer 2000). The diagnosis and progression of cancer disturbs patients' lives (Gurevich et al. 2002) who start frightening an imminent death and the suffering associated with the treatments (Caldeira et al. 2014).

Cancer affects individuals in all human dimensions: physical, psychological, social and spiritual (WHO 2014; Caldeira et al. 2016). These patients seem more susceptible to spiritual distress when they are diagnosed, during progression of the disease and at the end-of-life (Skalla and Ferrell 2015). Spiritual distress is also found in the literature as "existential suffering" (Bates 2016), "spiritual 
anguish" (Chaves et al. 2010), "spiritual pain" (Delgado-Guay et al. 2013), and "spiritual struggle" (Exline et al. 2013; Wilt et al. 2016).

Several studies have been conducted that support the existence of spiritual distress in cancer patients. In particular, Hui et al. (2011) conducted a study in patients with advanced cancer admitted to an acute palliative care unit and found an occurrence rate of $44.0 \%$ of spiritual distress. Gielen et al. (2017) found $17.4 \%$ of cancer patients in palliative care in India experience spiritual distress. Recently in Portugal, Caldeira et al. (2017) found $40.8 \%$ of cancer patients undergoing chemotherapy have spiritual distress.

Notwithstanding the subjective nature of spiritual distress, it can be assessed using various measures, tools and scales which have been developed, validated and translated in different countries and samples, such as, the Spiritual Distress Scale (Ku et al. 2010), Spiritual Distress Assessment Tool (Monod et al. 2012) and the Distress Thermometer (O'Donnell et al. 2013). Spiritual distress is an important issue in patient's response towards a health problem and is the title of a nursing diagnosis listed in the taxonomy II of NANDA International, Inc. (NANDA-I) since 1978. This nursing diagnosis is included in the domain 10-Principles of life-and in the class 3-Congruence between values/beliefs/acts (Herdman and Kamitsuru 2018). The most recent nursing diagnosis validation study has proposed a new definition of spiritual distress as follows: "a state of suffering associated with the meaning of his/her life, related to a connection to self, others, world, or a Superior" (Caldeira et al. 2013, p. 6). The assessment of spiritual distress is critical for getting an accurate diagnosis (Simão et al. 2015). The screening of patients' spiritual needs is considered an individual experience and ongoing process, which makes the assessment a complex process (Timmins and Caldeira 2017). Nevertheless, it is important to identify patients' spiritual needs, to promote and to provide holistic nursing care (Guerrero et al. 2011). Likewise, different nursing interventions have been described as adequate in supporting patients in overcoming spiritual distress, such as music therapy, guided imaging, therapeutic touch, progressive muscle relaxation, distant intercessory prayer, reminiscence therapy, affective support group and meditation (Guilherme and de Carvalho 2011).

Irrespective of all the scientific evidence on spiritual distress, a gap in implementing spiritual care in nursing practice remains. Several barriers to the provision of spiritual care have been described, such as, lack of training and time (Balboni et al. 2014), ignoring the spiritual aspect of care (Nascimento et al. 2010; Tiew et al. 2013), or misunderstanding the meaning of spirituality and the role in providing spiritual care (Rushton 2014). Spirituality and spiritual distress are individual experiences, and both require an individual approach. But, a deeper understanding of spiritual distress, based on the experience of having or living with spiritual distress, could be helpful in promoting an evidence-based practice and in supporting nurses in better diagnosing and intervening.

The aim of this review is to synthesis original qualitative research regarding spiritual distress of cancer patients, as qualitative research provides the information about participants' feelings (Sutton and Austin 2015), also a meaningful knowledge of people's real-life experiences besides it, allows for explaining a phenomenon which is poorly addressed (Polit and Beck 2014) in order to facilitate a deeper approach and understanding concerning this subject.

\section{Materials and Methods}

A literature review was undertaken, based on a search of the following electronic databases: CINAHL with Full text, PsycINFO, MEDLINE with Full text, MedicLatina, LILACS, SciELO, PubMed and Academic Search Complete. The search was conducted until 21 December 2017 using this search strategy: ("Cancer patients" OR "Cancer survivors" OR "Cancer survivorship" OR "Malignant tumor" OR “Neoplasms" OR “Oncologic patients" OR “Oncology patients" OR “Tumors") AND ("Spiritual distress" OR "Spiritual suffering" OR "Spiritual anguish" OR "Spiritual pain" OR "Spiritual struggle" OR "Existential pain" OR "Existential suffering"). Inclusion criteria were: original papers reporting qualitative research; cancer patients as population, regardless the type of cancer; written in English, 
Spanish, French or Portuguese. The process of selection and analysis of papers was independently conducted by two reviewers (Sampaio and Mancini 2007) (Table 1).

Table 1. Number of citations on the databases' search.

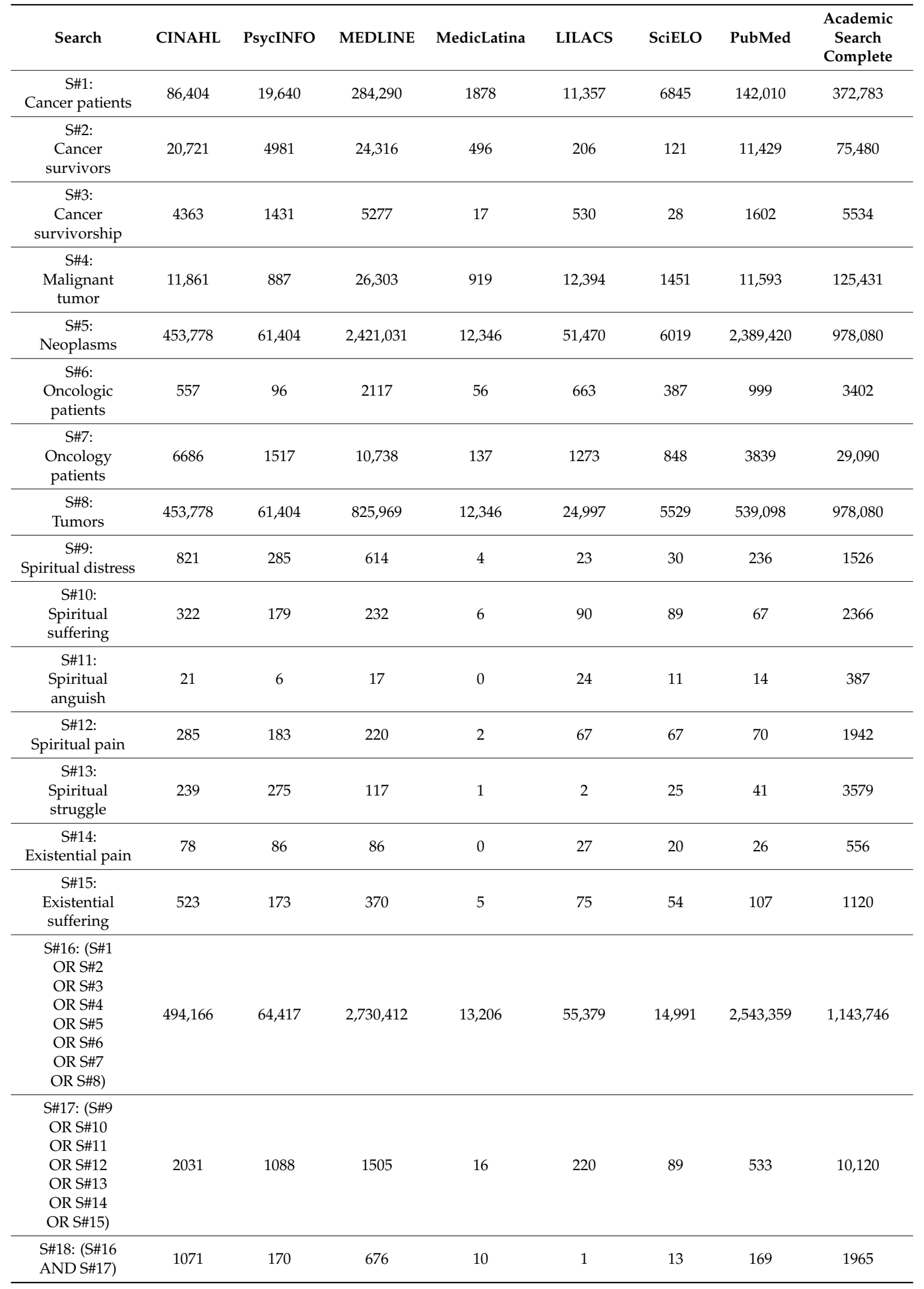


First, 4075 citations were identified, and after duplicates removal, a total of 2866 results were screened; 2593 were excluded after reading the title; 273 abstracts have been analyzed and 204 were excluded. A total of 69 full texts have been read and 23 full-texts were assessed for eligibility. The Critical Appraisal Skills Programme (CASP 2013) was selected at the beginning but, at this stage even the studies that did not meet the quality criteria were not excluded (Figure 1), as the authors perceived during the analysis that those studies had valuable information about spiritual distress and were critical for the aim of the review.

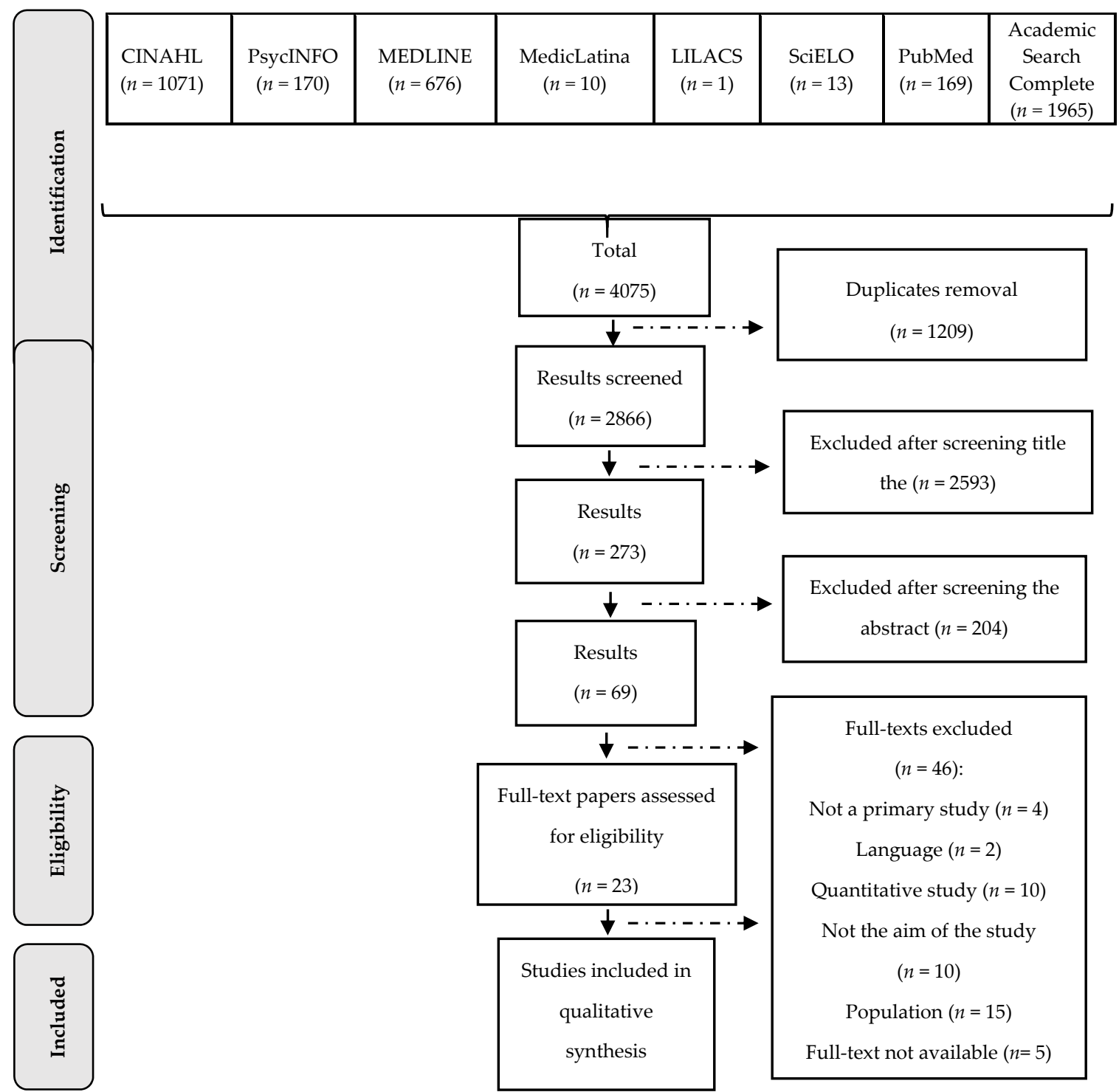

Figure 1. Study selection process.

The data extraction was performed in an Excel sheet, with predefined evaluation criteria previously stated in the review protocol, namely, author, year of publication, journal, title, objective, thematic area, setting, population, findings, methodology, data collection and themes regarding spiritual distress. Data were treated using descriptive statistics and content analysis. Citations concerning spiritual distress have been listed and independently analyzed. The sub-themes emerged based on the focus of each citation and then were compared. Next, the sub-themes were independently analyzed to be merged in themes. 


\section{Results}

Most studies were conducted in the USA $(n=7)$, few in Taiwan $(n=3)$, Iran $(n=2)$, and Australia, Canada, Israel, Japan, Malaysia, Spain, Sweden and Thailand $(n=1)$. Some studies involved the participation and collaboration of several countries, such as Finland and Sweden $(n=1)$, Iceland and UK $(n=1)$, and USA and Israel $(n=1)$. Most qualitative studies were published in 2002 and $2004(n=3)$, and the first study was published in 2001. Studies were published in 17 different journals, meanwhile the journals having the largest number of publications were Oncology Nursing Forum $(n=4)$, Support Care Cancer $(n=3)$, International Journal of Palliative Nursing, and Journal of Nursing Research $(n=2)$. Moreover, $54.2 \%$ of the studies were published in oncology journals and all 23 included studies were published in English.

Regarding the disciplines, nursing $(n=15)$ leaded the publications, followed by medicine $(n=5)$, theology $(n=2)$, and social science $(n=1)$. The qualitative methods most used were phenomenology $(n=15)$ (Albaugh 2003; Asgeirsdottir et al. 2013; Bentur et al. 2014; Chao et al. 2002; Chio et al. 2008; Coward and Kahn 2004; Hajdarevic et al. 2014; Lindholm et al. 2002; McGrath 2002; $\quad$ Montoya-Juarez et al. 2013; Nilmanat et al. 2015; $\quad$ Perreault and Bourbonnais 2005; Shih et al. 2009; Williams 2004, 2012), grounded theory $(n=3)$ (Farsi 2015; Halstead and Hull 2001; Kawa et al. 2003), case study $(n=3)$ (Balducci 2010; Cooper 2011; Loh 2004), descriptive method $(n=1)$ (Rahnama et al. 2012), and ethnography $(n=1)$ (Blinderman and Cherny 2005). About the phenomenology method, most studies used a Hermeneutic approach $(n=4)$ (Chao et al. 2002; Chio et al. 2008; Hajdarevic et al. 2014; Shih et al. 2009).

Concerning the time line, only two original studies were conducted using a longitudinal approach (Coward and Kahn 2004; Nilmanat et al. 2015). With regard to the data collection, interviews were the main method $(n=20)$, merging interviews and observation $(n=2)$ and narrative $(n=1)$. Most of the interviews were face-to-face, with one face to face and telephone (Cooper 2011). Generally the interviews were based on open-ended questions $(n=8)$ (Asgeirsdottir et al. 2013; Balducci 2010; Chio et al. 2008; Farsi 2015; McGrath 2002; Perreault and Bourbonnais 2005; Williams 2004, 2012), five with in depth interviews (Bentur et al. 2014; Chao et al. 2002; Farsi 2015; Shih et al. 2009; Williams 2004), semi-structured interviews $(n=6)$ (Chio et al. 2008; Hajdarevic et al. 2014; Halstead and Hull 2001; Montoya-Juarez et al. 2013; Perreault and Bourbonnais 2005; Rahnama et al. 2012), and unstructured interview $(n=2)$ (Chao et al. 2002; Williams 2012).

In relation to the number of participants, the samples ranged from one participant (Balducci 2010; Cooper 2011; Loh 2004) to 40 participants (Blinderman and Cherny 2005). The setting was mostly in the hospital $(n=14)$, with some at home and cancer center $(n=2)$, and in various settings $(n=7)$. Regarding, the sociodemographic characteristics of the participants, most of the studies includes both gender $(n=14)$, only female $(n=5)$, and male $(n=1)$. Most participants aged 18 years or older $(n=20)$. Participants have different type of cancers $(n=9)$, breast cancer $(n=5)$, hematological $(n=3)$, rhabdomyosarcoma of the leg $(n=1)$, melanoma $(n=1)$, and can't tell $(n=4)$. Participants' religiosity was not available in most studies $(n=17)$, in two studies all participants were Muslin, in two studies main participants were Buddhist, and in one study most were Jews.

Findings also revealed that the most common sampling technique resulted in convenience sampling $(n=11)$ (Asgeirsdottir et al. 2013; Bentur et al. 2014; Blinderman and Cherny 2005; Chio et al. 2008; Coward and Kahn 2004; Hajdarevic et al. 2014; Halstead and Hull 2001; Perreault and Bourbonnais 2005; Shih et al. 2009; Williams 2004, 2012), purposive $(n=4)$ (Chao et al. 2002; Farsi 2015; Nilmanat et al. 2015; Rahnama et al. 2012), snowball $(n=2)$ (Albaugh 2003; Lindholm et al. 2002), theoretical (Kawa et al. 2003), and intentional (Montoya-Juarez et al. 2013).

Content analysis was used in the included studies in order to analyze and obtain an understanding of the patient's experience of spiritual distress. Two major themes emerged in content analysis as follow: suffering and coping strategies to overcome spiritual distress (Figure 2). 


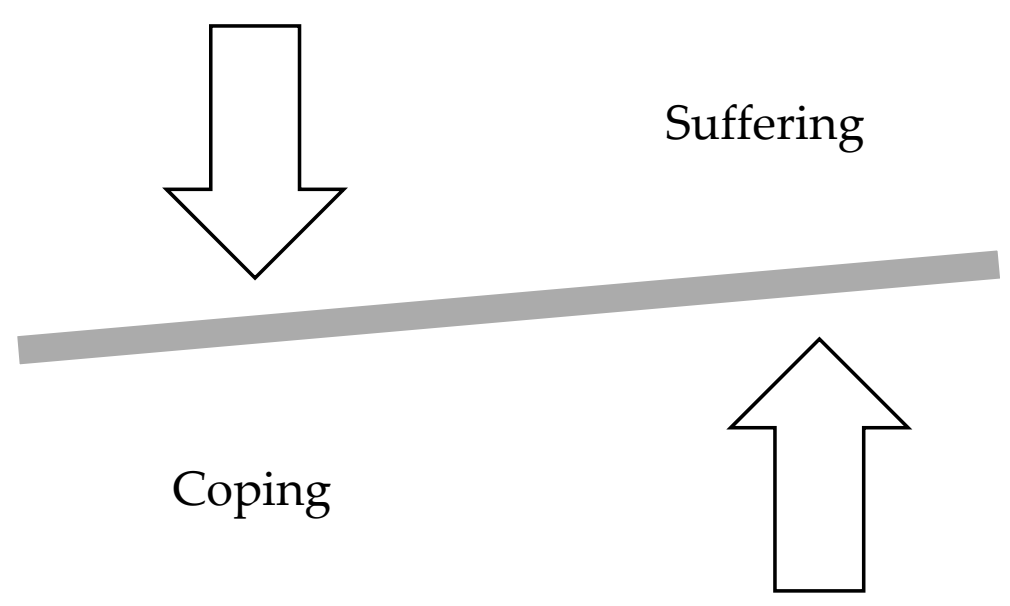

Figure 2. Major themes of spiritual distress.

Moreover, the major thematic areas are supported on the following sub-themes: theme suffering (sub-theme: alienation, anger, anxiety, body image, burden to family, crying, disconnected, fatalism, fear, forgiveness, good death/desire to die, guilt/punishment, hopelessness, impaired role performance, insomnia, lack of autonomy/dignity, lack of support relative and friends, loneliness, loss of self/lost identity, physical symptoms, refusing to see relatives, relationship with god, social isolation, uncertain future and worthlessness), and theme coping (sub-themes: connection with family/friends/self/spirituality/religion, connection to body and mind, hope, helping other patients, non-spiritual/religious therapies/practices, re-meaning, spiritual practices, support from family/friends, support from healthcare professionals, transcendence, transformation and trust in god/spiritual beliefs) (Table 2). 
Table 2. Major themes and sub-theme of spiritual distress in cancer patients from qualitative studies.

\begin{tabular}{|c|c|c|c|}
\hline Major Theme & Sub-Theme & Citation/Example & References \\
\hline Suffering & Alienation & $\begin{array}{l}\text { "Being empty and in a vacuum is a feeling of becoming bare, "empty in the head", } \\
\text { experiencing difficulty in thinking and living" Hajdarevic et al. (2014, p. 3) }\end{array}$ & $\begin{array}{l}\text { Hajdarevic et al. (2014); McGrath (2002); Nilmanat } \\
\text { et al. (2015) }\end{array}$ \\
\hline Suffering & Anger & "I am very angry" Loh (2004, p. 131) & $\begin{array}{l}\text { Asgeirsdottir et al. (2013); Chio et al. (2008); Loh } \\
\text { (2004); Nilmanat et al. (2015) }\end{array}$ \\
\hline Suffering & Anxiety & $\begin{array}{l}\text { "The evening I heard my diagnosis I immediately went to a friend's house for the night. The } \\
\text { next night I started feeling very anxious and I called a friend in California" } \\
\text { Coward and Kahn (2004, p. E2) } \\
\text { "I had a problem with that. I was more anxious" Williams (2012, p. E44) }\end{array}$ & $\begin{array}{l}\text { Blinderman and Cherny (2005); Chio et al. (2008) } \\
\text { Cooper (2011); Coward and Kahn (2004); Halstead } \\
\text { and Hull (2001); Kawa et al. (2003); Lindholm et al. } \\
\text { (2002); Nilmanat et al. (2015); Perreault and } \\
\text { Bourbonnais (2005); Williams (2012) }\end{array}$ \\
\hline Suffering & Body image & $\begin{array}{l}\text { "Think the loss of my hair is a major issue for me still, and just because every day you look in } \\
\text { the mirror and you see that I've had leukemia. It is a constant reminder, smack bang in my } \\
\text { face. And so I still find that extremely hard to deal with" McGrath (2002, p. 640) } \\
\text { 'I felt mutilated even if I still had my breast... I've got a hole.' } \\
\text { Perreault and Bourbonnais (2005, p. 515) }\end{array}$ & $\begin{array}{l}\text { Bentur et al. (2014); Blinderman and Cherny (2005); } \\
\text { Hajdarevic et al. (2014); Halstead and Hull (2001); } \\
\text { Kawa et al. (2003); McGrath (2002); Nilmanat et al. } \\
\text { (2015); Perreault and Bourbonnais (2005); } \\
\text { Shih et al. (2009) }\end{array}$ \\
\hline Suffering & Burden to family & $\begin{array}{l}\text { "I think I may feel happier and feel free if I die early. I do not want to be tortured any more. I } \\
\text { am very tired of having this kind of life. My children are very kind. But I wish to die early so } \\
\text { as not to be their burden" Chio et al. (2008, p. 740) } \\
\text { "He [her husband] saw that I had been crying, and then I said to him to be sure that he knew, } \\
\text { that the day I cannot take care of myself I want to be cared for in a hospice, and that the family } \\
\text { should not devote all their time to caring for me, and quite soon I felt how focus on the future } \\
\text { came much closer to me" (Hajdarevic et al. 2014, p. 4) }\end{array}$ & $\begin{array}{l}\text { Asgeirsdottir et al. (2013); Blinderman and Cherny } \\
\text { (2005); Chao et al. (2002); Chio et al. (2008); } \\
\text { Hajdarevic et al. (2014); Kawa et al. (2003); } \\
\text { Lindholm et al. (2002); Nilmanat et al. (2015); } \\
\text { Shih et al. (2009); Williams (2004) }\end{array}$ \\
\hline Suffering & Crying & $\begin{array}{l}\text { "You know when I last cried? About a week ago a couple came in here. I didn't see the man, he } \\
\text { stood behind the curtain. The woman was handsome, tall. She held a basket .... My son was } \\
\text { hospitalized here for some time, he passed away. These sweets are in memoriam'. [Weeping] I } \\
\text { started crying, that's beautiful!" Bentur et al. (2014, p. 6) } \\
\text { "Felt withdrawn ... (crying)... the pain is the scariest thing" } \\
\text { Nilmanat et al. (2015, p. 395) }\end{array}$ & $\begin{array}{l}\text { Bentur et al. (2014); Blinderman and Cherny (2005); } \\
\text { Chio et al. (2008); Hajdarevic et al. (2014); Nilmanat } \\
\text { et al. (2015); Perreault and Bourbonnais (2005) }\end{array}$ \\
\hline Suffering & Disconnected & "I feel disconnected" Halstead and Hull (Halstead and Hull 2001, p. 1538) & $\begin{array}{l}\text { Halstead and Hull (2001); Blinderman and Cherny } \\
\text { (2005); Coward and Kahn (2004); McGrath (2002); } \\
\text { Williams (2004); Williams (2012) }\end{array}$ \\
\hline
\end{tabular}


Table 2. Cont

\begin{tabular}{|c|c|c|c|}
\hline Major Theme & Sub-Theme & Citation/Example & References \\
\hline Suffering & Fatalism & $\begin{array}{l}\text { "The main change is that you see you are dying in a more realistic way" } \\
\text { Montoya-Juarez et al. (2013, p. 56) } \\
\text { "I'm already in the coffin and they can come to the funeral home and look at me like I'm on } \\
\text { display or something" Williams (2004, p. 35) } \\
\text { "But we always talk about everyday things and we don't talk about life. We pushed life aside." } \\
\text { Bentur et al. (2014, p. 3) }\end{array}$ & $\begin{array}{l}\text { Bentur et al. (2014); Blinderman and Cherny (2005); } \\
\text { Halstead and Hull (2001); Kawa et al. (2003); } \\
\text { Lindholm et al. (2002); Montoya-Juarez et al. (2013); } \\
\text { Lindholm et al. (2002); Perreault and Bourbonnais } \\
\text { (2005); Rahnama et al. (2012); Shih et al. (2009); } \\
\text { Williams (2004); Williams (2012) }\end{array}$ \\
\hline Suffering & Fear & $\begin{array}{l}\text { "I'm not ready to die ... I'm afraid ... When you die, you must say goodbye to your children } \\
\ldots \text { your spouse, friends and family, you must say goodbye to your roles and dreams ... " } \\
\text { Perreault and Bourbonnais (2005, p. 517) } \\
\text { "I did start experiencing fear, and I would have moments of doubt" } \\
\text { Halstead and Hull (2001, p. 1539) }\end{array}$ & $\begin{array}{l}\text { Asgeirsdottir et al. (2013); Balducci (2010); Bentur et } \\
\text { al. (2014); Blinderman and Cherny (2005); Chio et al. } \\
\text { (2008); Cooper (2011); Coward and Kahn (2004); } \\
\text { Halstead and Hull (2001); Kawa et al. (2003); } \\
\text { Lindholm et al. (2002); Nilmanat et al. (2015); } \\
\text { Perreault and Bourbonnais (2005); Williams (2004); } \\
\text { Williams (2012) }\end{array}$ \\
\hline Suffering & Forgiveness & $\begin{array}{l}\text { "If you don't have the feeling of hatred, then you can easily forgive others, no matter what has } \\
\text { happened" Rahnama et al. (2012, p. 4) }\end{array}$ & $\begin{array}{l}\text { Chao et al. (2002); Perreault and Bourbonnais (2005); } \\
\text { Rahnama et al. (2012) }\end{array}$ \\
\hline Suffering & $\begin{array}{l}\text { Good death/Desire to } \\
\text { die }\end{array}$ & $\begin{array}{l}\text { "I have been tolerating pain for a long time. In this torturing process, I with this tortured } \\
\text { body have been through a difficult time. I feel very painful. If I could die early, I would not } \\
\text { experience the torture anymore" Chio et al. (2008, p. } 739)\end{array}$ & $\begin{array}{l}\text { Chio et al. (2008); Kawa et al. (2003); } \\
\text { Nilmanat et al. (2015) }\end{array}$ \\
\hline Suffering & Guilt/Punishment & $\begin{array}{l}\text { "I feel so bad about all of this. Everyone knows it's my fault, but I can't help it. I knew it was } \\
\text { coming one day. I've been looking for it for years, smoking and all, being a mechanic and all. I } \\
\text { won't be around to see them grow up because of something I did to myself" } \\
\text { Williams (2004, p. 32) } \\
\text { "I knew that, although I had tried not to commit any sins, I had committed some. After } \\
\text { suffering cancer, I thought that this disease is a punishment from God and I was happy to } \\
\text { accept this" Farsi (2015, p. 4) }\end{array}$ & $\begin{array}{l}\text { Balducci (2010); Blinderman and Cherny (2005); } \\
\text { Chao et al. (2002); Chio et al. (2008); Cooper (2011); } \\
\text { Farsi (2015); Hajdarevic et al. (2014); Halstead and } \\
\text { Hull (2001); Williams (2004) }\end{array}$ \\
\hline Suffering & Hopelessness & $\begin{array}{l}\text { "Disability problems caused by the immobility of her legs led her to feel despair and } \\
\text { hopelessness" Chio et al. (2008, p. 740) } \\
\text { "It's worse not to know you have cancer and it's eating you away and suddenly you have no } \\
\text { hope... " Perreault and Bourbonnais (2005, p. 516) }\end{array}$ & $\begin{array}{l}\text { Chio et al. (2008); Perreault and Bourbonnais (2005); } \\
\text { McGrath (2002) }\end{array}$ \\
\hline Suffering & $\begin{array}{l}\text { Impaired role } \\
\text { performance }\end{array}$ & $\begin{array}{l}\text { "Actually I miss them so much. I am unable to care them anymore" Loh (2004, p. 131) } \\
\text { "The other problem is that I leave my children here and they have no one. My children don't } \\
\text { have anyone to fry an egg for them" Montoya-Juarez et al. (2013, p. 57) }\end{array}$ & $\begin{array}{l}\text { Bentur et al. (2014); Blinderman and Cherny (2005); } \\
\text { Chao et al. (2002); Kawa et al. (2003); Loh (2004); } \\
\text { McGrath (2002); Montoya-Juarez et al. (2013); } \\
\text { Perreault and Bourbonnais (2005); Williams (2004) }\end{array}$ \\
\hline
\end{tabular}


Table 2. Cont.

\begin{tabular}{|c|c|c|c|}
\hline Major Theme & Sub-Theme & Citation/Example & References \\
\hline Suffering & Insomnia & "I mean, I couldn't sleep, I couldn't do anything" Williams (2012, p. E43) & Nilmanat et al. (2015); Williams (2012) \\
\hline Suffering & $\begin{array}{c}\text { Lack of } \\
\text { autonomy/dignity }\end{array}$ & $\begin{array}{l}\text { "It is very difficult. I feel like I am in prison. I walk around with my nephrostomy bag. } \\
\text { My body does not function well" Blinderman and Cherny (2005, p. 374) } \\
\text { "Hope that they would treat me not as an invalid like's it's something catching. } \\
\text { (Williams 2004, p. 34) }\end{array}$ & $\begin{array}{l}\text { Blinderman and Cherny (2005); Chio et al. (2008); } \\
\text { Kawa et al. (2003); Montoya-Juarez et al. (2013); } \\
\text { Nilmanat et al. (2015); Perreault and Bourbonnais } \\
\text { (2005); Williams (2004) }\end{array}$ \\
\hline Suffering & $\begin{array}{l}\text { Feeling abandoned (by } \\
\text { relatives and friends) }\end{array}$ & "They took my money. But they do not take care of me" Chio et al. (2008, p. 739) & $\begin{array}{l}\text { Chio et al. (2008); McGrath (2002); Perreault and } \\
\text { Bourbonnais (2005) }\end{array}$ \\
\hline Suffering & Loneliness & $\begin{array}{l}\text { "I am weak, alone. I don't care" Blinderman and Cherny }(2005, \mathrm{p} .374) \\
\text { "I live every day knowing that my cancer is going to come back. It's a very lonely thing; it's } \\
\text { very difficult. Some days you can handle it, some days you can't" Williams }(2012, \mathrm{p} . \text { E46) } \\
\text { "I feel lonely and scared because of my declining health (during the evening and night in } \\
\text { particular)" Shih et al. (2009, p. E34) }\end{array}$ & $\begin{array}{l}\text { Blinderman and Cherny (2005); Cooper (2011); } \\
\text { Hajdarevic et al. (2014); Kawa et al. (2003); } \\
\text { Lindholm et al. (2002); McGrath (2002); Shih et al. } \\
\text { (2009); Williams (2012) }\end{array}$ \\
\hline Suffering & Questioning identity & $\begin{array}{l}\text { "... And I needed to talk and talk and talk and talk and talk. Until it got to the stage where I } \\
\text { had lost my identity" McGrath (2002, p. 642) }\end{array}$ & McGrath (2002); Perreault and Bourbonnais (2005) \\
\hline Suffering & Physical symptoms & $\begin{array}{l}\text { "I keep vomiting. If I did not have the urge to vomit, I would be able to walk without having to } \\
\text { ask for help from others ... II] just wish that I would not need to vomit, so I could walk and } \\
\text { care for myself" Rahnama et al. (2012, p. 397) } \\
\text { "I had so much phlegm I could hardly breathe half the time. I was a wreck physically, destroyed } \\
\text {... "Williams (2012, p. E43) }\end{array}$ & $\begin{array}{l}\text { Blinderman and Cherny (2005); Chio et al. (2008); } \\
\text { Farsi (2015); Kawa et al. (2003); McGrath (2002); } \\
\text { Nilmanat et al. (2015); Rahnama et al. (2012); Shih et } \\
\text { al. (2009); Williams (2012); Williams (2004) }\end{array}$ \\
\hline Suffering & $\begin{array}{l}\text { Refuses to interact } \\
\text { with significant other }\end{array}$ & "They are fine. All of them are in school. I told them not to come" Loh (2004, p. 131) & Loh (2004) \\
\hline Suffering & Relationship with God & "At first I was angry at God" Blinderman and Cherny $(2005$, p. 376) & Blinderman and Cherny (2005) \\
\hline Suffering & Social isolation & $\begin{array}{l}\text { "Yes, I felt socially isolated. I didn't feel like leaving my home or speaking with others for } \\
\text { months" Blinderman and Cherny (2005, p. 375) } \\
\text { "I fear going out... [I am] not strong ... [I am afraid of] getting infected ... [I] just sit here } \\
\text { (at the window), look at other people outside. Others are good [healthy] ... can walk about } \\
\text { and work, but I hide in the house. I cannot do anything ... (sigh) ... and think why it has to } \\
\text { be me who is in this condition" Nilmanat et al. (2015, p. 396) } \\
\text { "I don't talk to many people any more. I don't hang around with the same friends and } \\
\text { everything. My mother is gone and I'm not that close to my daddy. I haven't kept in touch } \\
\text { with any of my high school friends, so I guess it would be hard to find out" } \\
\text { Williams (2004, p. 34) }\end{array}$ & $\begin{array}{l}\text { Blinderman and Cherny (2005); Kawa et al. (2003); } \\
\text { Nilmanat et al. (2015); Perreault and Bourbonnais } \\
\text { (2005); Williams (2004) }\end{array}$ \\
\hline
\end{tabular}


Table 2. Cont.

\begin{tabular}{|c|c|c|c|}
\hline Major Theme & Sub-Theme & Citation/Example & References \\
\hline Suffering & Uncertain future & $\begin{array}{l}\text { "In the present situation, I am not healthy. It is true... I cannot talk about my future, } \\
\text { because my physical condition tomorrow is unknown" Kawa et al. (2003, p. 484) }\end{array}$ & $\begin{array}{l}\text { Coward and Kahn (2004); Hajdarevic et al. (2014); } \\
\text { Halstead and Hull (2001); Kawa et al. (2003); } \\
\text { Perreault and Bourbonnais (2005); Williams (2004); } \\
\text { Williams (2012) }\end{array}$ \\
\hline Suffering & Worthlessness & $\begin{array}{l}\text { "I am not afraid of losing my dignity. There is not much to lose" } \\
\text { Blinderman and Cherny }(2005, \text { p. 375) }\end{array}$ & Blinderman and Cherny (2005) \\
\hline Coping & $\begin{array}{l}\text { Connection with } \\
\text { family/friends/self/ } \\
\text { spirituality/religion }\end{array}$ & $\begin{array}{l}\text { "Connect with friends on an intellectual level" Blinderman and Cherny (2005, p. 376) } \\
\text { "Doris reported that these rituals helped her feel connected to God, and that she felt supported } \\
\text { and comforted by both priests' visits" Cooper (2011, p. 29) }\end{array}$ & $\begin{array}{l}\text { Asgeirsdottir et al. (2013); Bentur et al. (2014); } \\
\text { Blinderman and Cherny (2005); Cooper (2011); } \\
\text { Coward and Kahn (2004); Halstead and Hull (2001); } \\
\text { Kawa et al. (2003); Lindholm et al. (2002); Rahnama } \\
\text { et al. (2012); Perreault and Bourbonnais (2005); } \\
\text { Williams (2012) }\end{array}$ \\
\hline Coping & $\begin{array}{l}\text { Connection to body } \\
\text { and mind }\end{array}$ & $\begin{array}{l}\text { "If the nausea comes, I fight it. You're not going to vomit, no, no! I hold the vomit back and it } \\
\text { hurts in my chest to hold it back. If I'm in a good mental and emotional state, I can hold it in." } \\
\text { (Bentur et al. 2014, p. 4) } \\
\text { "Once I am calm, I can tolerate my physical problems more easily" } \\
\text { Rahnama et al. (2012, p. 5) } \\
\text { "My mental health is connected to my physical health" } \\
\text { Blinderman and Cherny (2005, p. 376) }\end{array}$ & $\begin{array}{l}\text { Bentur et al. (2014); Blinderman and Cherny (2005); } \\
\text { Chio et al. (2008); Rahnama et al. (2012) }\end{array}$ \\
\hline Coping & Hope & "I've got hope because I'm still alive" Perreault and Bourbonnais (2005, p. 516) & $\begin{array}{l}\text { Asgeirsdottir et al. (2013); Blinderman and Cherny } \\
\text { (2005); Chao et al. (2002); Cooper (2011); Perreault } \\
\text { and Bourbonnais (2005) }\end{array}$ \\
\hline Coping & Helping other patients & $\begin{array}{l}\text { "We met in the hospital. Then, we encouraged each other and made fun of each other, which } \\
\text { made us feel better" Chio et al. (2008, p. 740) } \\
\text { "O yes, I still have the potential to help people, to make their lives a little better" } \\
\text { Cooper (2011, p. 25) }\end{array}$ & Chao et al. (2002); Chio et al. (2008); Cooper (2011) \\
\hline Coping & $\begin{array}{l}\text { Non-spiritual/religious } \\
\text { therapies/practices }\end{array}$ & $\begin{array}{l}\text { "I've read since the transplant, you know, I've had a lot of time to read .... There is so much, } \\
\text { you know, with New Age thinking and esoteric thinking and all that sort of thing, that I can't } \\
\text { make up my mind [laughs]. But I enjoy reading about it, it's very interesting." } \\
\text { McGrath (2002, p. 239) }\end{array}$ & $\begin{array}{l}\text { Asgeirsdottir et al. (2013); Balducci (2010); Bentur et } \\
\text { al. (2014); Blinderman and Cherny (2005); Chao et al. } \\
\text { (2002); Chio et al. (2008); Cooper (2011); Hajdarevic } \\
\text { et al. (2014); Halstead and Hull (2001); McGrath } \\
\text { (2002); Perreault and Bourbonnais (2005) }\end{array}$ \\
\hline Coping & Re-meaning & $\begin{array}{l}\text { "Life has become for me a privileged experience of being in love. To love people surrounding } \\
\text { me... to enjoy every moment... It's to choose, not to endure, but to choose" } \\
\text { Perreault and Bourbonnais }(2005, \mathrm{p} .517)\end{array}$ & $\begin{array}{l}\text { Albaugh (2003); Balducci (2010); Bentur et al. (2014); } \\
\text { Blinderman and Cherny (2005); Cooper (2011); } \\
\text { Hajdarevic et al. (2014); Halstead and Hull (2001); } \\
\text { Perreault and Bourbonnais (2005) }\end{array}$ \\
\hline
\end{tabular}


Table 2. Cont.

\begin{tabular}{|c|c|c|c|}
\hline Major Theme & Sub-Theme & Citation/Example & References \\
\hline Coping & Spiritual practices & $\begin{array}{l}\text { "I believe very strongly in the power of prayer, and I feel that everybody that is praying for me } \\
\ldots \text {.. everybody who talked to me either when they're at church or friends around me, I thought } \\
\text { that was wonderful ... A prayer is like a gigantic hug from a number of people, all the people } \\
\text { that tell me that they prayed for me. It's just something that encompasses me, a good positive } \\
\text { feeling that lifts me" Albaugh }(2003, \text { p. 595) }\end{array}$ & $\begin{array}{l}\text { Albaugh (2003); Asgeirsdottir et al. (2013); } \\
\text { Blinderman and Cherny (2005); Chio et al. (2008); } \\
\text { Cooper (2011); Hajdarevic et al. (2014); Halstead } \\
\text { and Hull (2001); Loh (2004); Perreault and } \\
\text { Bourbonnais (2005); Rahnama et al. (2012) }\end{array}$ \\
\hline Coping & $\begin{array}{l}\text { Support from } \\
\text { family/friends }\end{array}$ & $\begin{array}{l}\text { "My son had told his wife: May family has a great influence on my morale. I didn't lose my } \\
\text { heart because my mom and others treated me very well" Rahnama et al. (2012, p. 5) } \\
\text { "I couldn't make a decision on therapy options without the help of my family and friends. } \\
\text { Without them, I just wanted to die immediately" Shih et al. (2009, p. E34) }\end{array}$ & $\begin{array}{l}\text { Bentur et al. (2014); Blinderman and Cherny (2005); } \\
\text { Chio et al. (2008); Hajdarevic et al. (2014); Halstead } \\
\text { and Hull (2001); Perreault and Bourbonnais (2005); } \\
\text { Rahnama et al. (2012); Shih et al. (2009) }\end{array}$ \\
\hline Coping & $\begin{array}{l}\text { Support from } \\
\text { healthcare } \\
\text { professionals }\end{array}$ & $\begin{array}{l}\text { "A psychologist often came to see me. I could release the pressure suppressed in my mind } \\
\text { through talking and communicating with him. For example, a while ago, one patient who was } \\
\text { my roommate in the hospital died. Two days later, another one died. I felt so scared. He took } \\
\text { me to the living room and talked to me. After talking with him, I felt } \\
\text { better" Chio et al. (2008, p. 740) } \\
\text { "With the nurse's encouragement, my children told me that they needed me so much. I know it } \\
\text { is difficult for us Taiwanese to say so. As a dying person, I'm so content and this has } \\
\text { reaffirmed my strong sense of belonging" Shih et al. (2009, p. E35) }\end{array}$ & $\begin{array}{l}\text { Blinderman and Cherny (2005); Chao et al. (2002); } \\
\text { Chio et al. (2008); Shih et al. (2009) }\end{array}$ \\
\hline Coping & Transcendence & $\begin{array}{l}\text { "There is just something that is greater than you. You are not under its control or anything } \\
\text { like that. There is some power that is higher than you, which I want to call a good one; a force } \\
\text { that helps you in your daily difficulties and } \\
\text { duties" Asgeirsdottir et al. (Asgeirsdottir et al. 2013, p. 1449) }\end{array}$ & $\begin{array}{l}\text { Asgeirsdottir et al. (2013); Coward and Kahn (2004); } \\
\text { Chio et al. (2008); Farsi (2015); Shih et al. (2009); } \\
\text { Williams (2012) }\end{array}$ \\
\hline Coping & Transformation & $\begin{array}{l}\text { "I guess I would say that a life-threatening thing happening to you is not the worst thing that } \\
\text { can happen to you, it can make you a better person" Albaugh (2003, p. 597) }\end{array}$ & Albaugh (2003); Perreault and Bourbonnais (2005) \\
\hline Coping & $\begin{array}{l}\text { Trust in God/Spiritual } \\
\text { beliefs }\end{array}$ & $\begin{array}{l}\text { "I was upset, but I didn't claim it. I put it into God's hands." Ciele said, "I really gave it all } \\
\text { over to God: 'I don't know what to do, but I trust that you will help me figure it out" } \\
\text { Coward and Kahn (2004, p. E4) } \\
\text { "Religious support has been like cool drink of water and a crutch to help me on my daily walk } \\
\text { through the desert" Shih et al. (2009, p. E35) }\end{array}$ & $\begin{array}{l}\text { Albaugh (2003); Bentur et al. (2014); Blinderman } \\
\text { and Cherny (2005); Chao et al. (2002); Chio et al. } \\
\text { (2008); Cooper (2011); Coward and Kahn (2004); } \\
\text { Farsi (2015); Hajdarevic et al. (2014); Halstead and } \\
\text { Hull (2001); Loh (2004); Perreault and Bourbonnais } \\
\text { (2005); Rahnama et al. (2012); Shih et al. (2009) }\end{array}$ \\
\hline
\end{tabular}




\section{Discussion}

This review has aimed to provide a synthesis of qualitative studies regarding spiritual distress in cancer patients. A recent overview about spiritual distress (des Ordons et al. 2018) involved both patient and family experiences within inpatient settings, including mixed-methods, qualitative and quantitative studies, is bringing interesting findings and a broader perspective of spiritual distress. This review focused only on the synthesis of qualitative studies including cancer patients, and excluding family, aiming at a deeper insight into the individual experience of spiritual distress. This deeper approach of spiritual distress in cancer patients aims to better understand and increase the knowledge in this topic, which may enable and raise awareness in the assessment of spiritual distress in the future, in clinical practice, education, and in research.

The research methods in this review are mainly phenomenology and grounded theory. Phenomenology has the ability to uncover the essence and meaning of a phenomenon which is lived by individuals (Polit and Beck 2014). Interviews were mainly used method for data collection, as expected in qualitative research, as it provides a more comprehensive and global view on a deeper phenomenon (Alshenqeeti 2014).

Qualitative research normally uses non-random samples in order to collect data from participants (Polit and Beck 2014). Our findings suggest, that convenience samping was the most used sampling technique, although it's considered the least rigorous procedure, that does not require much effort and time to conduct, is adequate to these type of studies (Elfil and Negida 2017; Shorten and Moorley 2014).

After analyzing the timeframe of the studies, only two studies were longitudinal, which represents a small percentage of the studies included. In fact, a recent overview of the research methods used in the research about spirituality in nursing found that only a small percentage of studies are longitudinal, and recommendations have been made to increase the use of that design in the study of patients' spirituality over time (Martins et al. 2017).

The content analysis of the 23 articles resulted in two major themes: suffering and coping. In a study that found the prevalence of spiritual distress of $40.8 \%$ in cancer patients, $98.6 \%$ of patients having spiritual distress were in suffering (Caldeira et al. 2017). According to NANDA-I, the major defining characteristics of spiritual distress are anxiety, crying, fatigue, fear, insomnia, questioning identity, questioning meaning of life and questioning meaning of suffering (Herdman and Kamitsuru 2018, p. 375). The defining characteristics of anxiety, crying, fatigue, fear, insomnia and questioning identity are coincident with the sub-themes of suffering in this review. Additionally, Carlson et al. (2004) conducted a study with 3095 cancer patients over a four-week period, and the results displayed that patients reported having fatigue (48.5\%) and anxiety $(24.0 \%)$. Davis et al. (2013) found that female cancer patients are more likely to have insomnia $(70.0 \%)$ than males (51\%). Rydé et al. (2007) concluded that crying could be considered a way of expressing urgent needs, an expression for an inner emotional force, and may help to reduce tension, regardless of being energy consuming. Vrinten et al. (2017) identified what people fear the most about cancer, and the findings highlight that patients perceive cancer as an unpredictable and indestructible enemy, fear the proximity and the possibility of dying with cancer, and fear the emotional, physical and social implications of being known as a cancer patient.

Still, according do NANDA-I, other minor defining characteristics of spiritual distress are coincident with this review, such as: alienation, anger, guilt, hopelessness, feeling abandoned, and refuses to interact with significant other. The latter defining characteristics are related to the person's connection with self, others, world and Superior Being (Herdman and Kamitsuru 2018).

The emergence of the major theme "suffering" in spiritual distress on cancer patients is consistent with Wilson et al. (2007), which found that $25.7 \%$ of cancer patients were suffering at a moderate to-extreme level and $24.9 \%$, mildly. In a clinical validation study of the nursing diagnosis "spiritual distress", Caldeira et al. (2013) identified that the most sensitive defining characteristic was "expressed suffering". In this review, suffering is a major theme and was expressed throughout in all dimensions of cancer patients. In fact, suffering is considered a multidimensional (Best et al. 2015; Wilson et al. 2007), 
complex (Barton-Burke et al. 2008), and individual experience related to the culture and context of the patients' lives (Wein 2011). In fact, the 25 sub-themes related to suffering underline the complexity of suffering. Spiritual distress is mainly considered as a condition of suffering (Simão et al. 2015), and a state of suffering associated to lack of meaning in life (Caldeira et al. 2017). In this review, finding meaning in suffering has been found critical while living with cancer. The role of meaning as a response to a time of crisis, such as cancer, can be operationalized as an adaptation process (Fife 2005).

Coping is a major theme is this review. A recently published concept analysis of coping in cancer patients defined coping "as a process of dealing with stressful events by means of cognitive appraisal, purposeful efforts, and use of available supports and resources in order to achieve physiological and psychological adjustment" (Yang 2018, p. 30). Furthermore, Nyatanga (2014) stated that coping is a response that patients must use to adjust and adapt when it comes to cancer, and this response is performed in many ways. The importance of using coping strategies is emphasized in the study conducted by Danhauer et al. (2009) that relates the use of coping strategies in improving the quality of life in younger women with breast cancer.

In this review, the findings suggest that coping was found a way to overcome suffering by cancer patients with spiritual distress, which was accomplished by several strategies based on patients' connection with family/friends/self/spirituality/religion, connection to body and mind, hope, helping other patients, non-spiritual/religious therapies/practices, re-meaning, spiritual practices, support from family/friends, support from healthcare professionals, transcendence, transformation and trust in God/spiritual beliefs. This review revealed that cancer patients use coping strategies, such as spiritual and religious practices. These patients were found to have a high level of spiritual coping, mainly religious coping strategies (Khodaveirdyzadeh et al. 2016). Thus, religion plays a major role in meaning and is one coping strategy used by cancer patients (Barton-Burke et al. 2008).

Transcendence was also one of the sub-themes of coping. Advanced cancer patients' spiritual experiences of transcendence have been linked to physical domain (less pain, sometimes less dyspnea) and psychological domain (less anxiety, better coping with illness, life and death) (Renz et al. 2015). Regarding the sub-theme support from healthcare professionals, Nyatanga (2014) mentioned that healthcare professionals play an important role in supporting the patient's ability to adjust and cope with the illness.

Spiritual distress seems an experience patient feel in two dimensions: on one hand, suffering, that is a negative condition; but, on the other hand, the positive and transformative dimension expressed in coping strategies to overcome and transform suffering.

The findings of this review should be analyzed taking into consideration some limitations. The validation of the themes and sub-themes and the synthesis of the qualitative data were based only on the citations in the original papers. This review brings an inaugural insight, grounded in a synthesis of qualitative studies concerning cancer patients' spiritual distress.

\section{Conclusions}

Spiritual distress is an intimate, deep and suffering experience in life, which requires coping strategies and involves spiritual values and beliefs. Spiritual distress may occur in cancer patients, and healthcare providers should be aware of this experience and recognize spiritual distress. Therefore, assessing spiritual needs and recognizing spiritual distress in cancer patients is considered critical in providing holistic care particularly in nursing. Spiritual distress comprises several manifestations and consequently, nurses require solid, ethical and compassionate relationships with cancer patients and their families, in order to facilitate the assessment of spiritual needs.

Spiritual distress comprises several manifestations and therefore nurses should be aware of self and their own limitations in providing spiritual care. Whenever necessary, they should request the support of another member of the healthcare team or refer patients to those who are able to provide an accountable intervention. 
Author Contributions: H.M. and S.C. conceived and designed the study, analyzed the data and wrote the paper. Funding: This research received no external funding.

Conflicts of Interest: The authors declare no conflict of interest.

\section{References}

Albaugh, Jeffrey A. 2003. Spirituality and Life-Threatening Illness: A Phenomenologic Study. Oncology Nursing Forum 30: 593-98. [CrossRef] [PubMed]

Alshenqeeti, Hamza. 2014. Interviewing as a Data Collection Method: A Critical Review. English Linguistics Research 3: 39-45. [CrossRef]

American Cancer Society. 2018. Cancer Facts \& Figures 2018. Atlanta: American Cancer Society, p. 72.

Asgeirsdottir, Gudlaug Helga, Einar Sigurbjörnsson, Rannveig Traustadottir, Valgerdur Sigurdardottir, Sigridur Gunnarsdottir, and Ewan Kelly. 2013. "To Cherish Each Day as it Comes": A Qualitative Study of Spirituality Among Persons Receiving Palliative Care. Supportive Care in Cancer: Official Journal of the Multinational Association of Supportive Care in Cancer 21: 1445-51. [CrossRef] [PubMed]

Balboni, Michael J., Adam Sullivan, Andrea C. Enzinger, Zachary D. Epstein-Peterson, Yolanda D. Tseng, Christine Mitchell, Joshua Niska, Angelika Zollfrank, Tyler J. VanderWeele, and Tracy A. Balboni. 2014. Nurse and Physician Barriers to Spiritual Care Provision at the End of Life. Journal of Pain and Symptom Management 48: 400-10. [CrossRef] [PubMed]

Balducci, Lodovico. 2010. Beyond Quality of Life: The Meaning of Death and Suffering in Palliative Care. Asian Pacific Journal of Cancer Prevention: APJCP 11: 41-44. [PubMed]

Barton-Burke, Margaret, Raimundo C. Barreto Jr., and Lisa I. S. Archibald. 2008. Suffering as a Multicultural Cancer Experience. Seminars in Oncology Nursing 24: 229-36. [CrossRef] [PubMed]

Bates, Alan T. 2016. Addressing Existential Suffering. British Columbia Medical Journal 58: 268-73.

Bentur, Netta, Daphna Yaira Stark, Shirli Resnizky, and Zvi Symon. 2014. Coping Strategies for Existencial and Spiritual Suffering in Israeli Patients with Advanced Cancer. Israel Journal of Health Policy Research 3: 21. [CrossRef] [PubMed]

Best, Megan, Lynley Aldridge, Phyllis Butow, Ian Oliver, Melanie Price, and Fleur Webster. 2015. Assessment of Spiritual Suffering in the Cancer Context: A Systematic Literature Review. Palliative and Supportive Care 13: 1335-61. [CrossRef] [PubMed]

Blinderman, Craig D., and Nathan I. Cherny. 2005. Existential Issues Do Not Necessarily Result in Existential Suffering: Lessons from Cancer Patients in Israel. Palliative Medicine 19: 371-80. [CrossRef] [PubMed]

Caldeira, Sílvia, Emília Campos de Carvalho, and Margarida Vieira. 2013. Spiritual Distress-Proposing a New Definition and Defining Characteristics. International Journal of Nursing Knowledge 24: 77-84. [CrossRef] [PubMed]

Caldeira, Sílvia, Emília Campos de Carvalho, and Margarida Vieira. 2014. Between Spiritual Wellbeing and Spiritual Distress: Possible Related factors in Elderly Patients with Cancer. Revista Latino-Americana de Enfermagem (RLAE) 22: 28-34. [CrossRef] [PubMed]

Caldeira, Sílvia, Fiona Timmins, Emília Campos de Carvalho, and Margarida Vieira. 2016. Nursing Diagnosis of "Spiritual Distress" in Women with Breast Cancer Prevalence and Major Defining Characteristics. Cancer Nursing 39: 321-27. [CrossRef] [PubMed]

Caldeira, Sílvia, Fiona Timmins, Emília Campos de Carvalho, and Margarida Vieira. 2017. Clinical Validation of the Nursing Diagnosis Spiritual Distress in Cancer Patients Undergoing Chemotherapy. International Journal of Nursing Knowledge 28: 44-52. [CrossRef] [PubMed]

Carlson, Linda, Maureen Angen, Jodi Cullum, Eillen Goodey, Jan Koopmans, Lisa Lamont, J.H. MacRae, M. Martin, Guy Pelletier, John Robinson, and et al. 2004. High Levels of Untreated Distress and Fatigue in Cancer Patients. British Journal of Cancer 90: 2297-94. [CrossRef] [PubMed]

CASP. 2013. Critical Appraisal Skills Programme. Available online: http://www.casp-uk.net/\#!checklists/cb36 (accessed on 16 January 2018).

Chao, Co-Shi Chantal, Ching-Huey Chen, and Miaofen Yen. 2002. The Essence of Spirituality of Terminally Ill Patients. Journal of Nursing Research (Taiwan Nurses Association) 10: 237-44. [CrossRef] 
Chaves, Erika de Cássia Lopes, Emília Campos de Carvalho, and Vanderlei José Hass. 2010. Validação do Diagnóstico de Enfermagem Angústia Espiritual: Análise por Especialistas. Acta Paulista de Enfermagem 23: 264-70. [CrossRef]

Chio, Chung-Ching, Fu-Jin Shih, Jeng-Fong Chiou, Hsiao-Wei Lin, Fei-Hsiu Hsiao, and Yu-Ting Chen. 2008. The Lived Experiences of Spiritual Suffering and the Healing Process among Taiwanese Patients with Terminal Cancer. Journal of Clinical Nursing 17: 735-43. [CrossRef] [PubMed]

Cooper, Rhonda S. 2011. Case Study of a Chaplain's Spiritual Care for a Patient with Advanced Metastatic Breast Cancer. Journal of Health Care Chaplaincy 17: 19-37. [CrossRef] [PubMed]

Coward, Doris Dickerson, and David L. Kahn. 2004. Resolution of Spiritual Disequilibrium by Women Newly Diagnosed with Breast Cancer. Oncology Nursing Forum 31: 1-8.

Danhauer, Suzanne C., Sybil L. Crawford, Deborah F. Farmer, and Nancy E. Avis. 2009. A Longitudinal Investigation of Coping Strategies and Quality of Life Among Younger Women with Breast Cancer. Journal of Behavioral Medicine 32: 371-79. [CrossRef] [PubMed]

Davis, Mellar P., Dilara Khoshknabi, Declan Walsh, Ruth Lagman, and Alexandra Platt. 2013. Insomnia in Patients with Advanced Cancer. American Journal of Hospice \& Palliative Medicine 31: 365-73. [CrossRef]

Delgado-Guay, Marvin Omar, Henrique A. Parsons, David Hui, Maxine G. De la Cruz, Steven Thorney, and Eduardo Bruera. 2013. Spirituality, Religiosity, and Spiritual Pain among Caregivers of Patients with Advanced Cancer. American Journal of Hospice and Palliative Medicine 30: 455-61. [CrossRef] [PubMed]

Elfil, Mohamed, and Ahmed Negida. 2017. Sampling Methods in Clinical Research: An Educational Review. Emergency 5: E52. [PubMed]

Exline, Julie J., Maryjo Prince-Paul, Briana L. Root, and Karen S. Peereboom. 2013. The Spiritual Struggle of Anger toward God: A Study with Family Members of Hospice Patients. Journal of Palliative Medicine 16: 369-75. [CrossRef] [PubMed]

Farsi, Zahra. 2015. The Meaning of Disease and Spiritual Responses to Stressors in Adults with Acute Leukemia Undergoing Hematopoietic Stem Cell Transplantation. Journal of Nursing Research 23: 209-97. [CrossRef] [PubMed]

Fife, Betsy. 2005. The Role of Constructed Meaning in Adaptation to the Onset of Life-Threatening Illness. Social Science \& Medicine 61: 2132-43. [CrossRef]

Gielen, Joris, Sushma Bhatnagar, and Santosh K. Chaturvedi. 2017. Prevalence and Nature of Spiritual Distress Among Palliative Care Patients in India. Journal of Religion and Health 56: 530-44. [CrossRef] [PubMed]

Guerrero, Giselle Patrícia, Márcia Maria Fontão Zago, Namie Okino Sawada, and Maria Helena Pinto. 2011. Relação Entre Espiritualidade e Câncer: Perspectiva do Paciente. Revista Brasileira de Enfermagem 64: 53-59. [CrossRef] [PubMed]

Guilherme, Caroline, and Emília Campos de Carvalho. 2011. Spiritual Distress in Cancer Patients: Nursing Interventions. Journal of Nursing UFPE/Revista de Enfermagem UFPE 5: 290-94. [CrossRef]

Gurevich, Maria, Gerald M. Devins, and Gary M. Rodin. 2002. Stress Response Syndromes and Cancer: Conceptual and Assessment Issues. Psychosomatics 43: 259-81. [CrossRef] [PubMed]

Hajdarevic, Senada, Birgit H. Rasmussen, and Åsa Hörnsten. 2014. You Never Know When Your Last Day Will Come and Your Trip Will Be Over-Existential Expressions from a Melanoma Diagnosis. European Journal of Oncology Nursing 18: 355-61. [CrossRef] [PubMed]

Halstead, Marilyn Tuls, and Margaret Hull. 2001. Struggling with Paradoxes: The Process of Spiritual Development in Women with Cancer. Oncology Nursing Forum 28: 1534-44. [PubMed]

Herdman, Heather T., and Shigemi Kamitsuru, eds. 2018. NANDA: NANDA International Nursing Diagnoses: Definitions and Classification 2018-2010, 11th ed. Chichester/Ames: Wiley-Blackwell, 512p. First published 1994.

Hui, David, Maxine de la Cruz, Steve Thorney, Henrique A. Parsons, Marvin Delgado-Guay, and Eduardo Bruera. 2011. The Frequency and Correlates of Spiritual Distress Among Patients with Advanced Cancer Admitted to an Acute Palliative Care Unit. The American journal of Hospice E Palliative Care 28: 264-70.

Kawa, Masako, Mami Kayama, Etsuko Maeyama, Noriko Iba, Hisayuki Murata, Yuka Imamura, Tikayo Koyama, and Michiyo Mizuno. 2003. Distress of Inpatients with Terminal Cancer in Japanese Palliative Care Units: From the Viewpoint of Spirituality. Supportive Care in Cancer: Official Journal of the Multinational Association of Supportive Care in Cancer 11: 481-90. [CrossRef] [PubMed] 
Khodaveirdyzadeh, Roghieh, Rabee Rahimi, Azad Rahmani, Akram Ghahramanian, Naser Kodayari, and Jamal Eivazi. 2016. Spiritual/Religious Coping Strategies and Their Relationship with Illness Adjustment among Iranian Breast Cancer Patients. Asian Pacific Journal of Cancer Prevention 17: 4095-99. [PubMed]

$\mathrm{Ku}$, Ya-Lie, Shih-Ming Kuo, and Ching-Yi Yao. 2010. Establishing the Validity of a Spiritual Distress Scale for Cancer Patients Hospitalized in Southern Taiwan. International Journal of Palliative Nursing 16: 134-38. [CrossRef] [PubMed]

Lindholm, Lisbet, Arne Rehnsfeldt, Maria Arman, and Elisabeth Hamrin. 2002. Significant Others' Experience of Suffering When Living with Women with Breast Cancer. Scandinavian Journal of Caring Sciences 16: 248-55. [CrossRef] [PubMed]

Loh, Ken Yin. 2004. Spiritual Distress in a Terminally Ill Patient with Breast Cancer. International Journal of Palliative Nursing 10: 131-32. [CrossRef] [PubMed]

Martins, Helga, Joana Romeiro, and Sílvia Caldeira. 2017. Spirituality in Nursing: An Overview of Research Methods. Religions 8: 226. [CrossRef]

McGrath, Pam. 2002. Creating a Language for "Spiritual Pain" Through Research: A Beginning. Support Care Cancer 10: 637-46. [CrossRef] [PubMed]

Monod, Stefanie, Estelle Martin, Brenda Spencer, Etienne Rochat, and Christophe Bula. 2012. Validation of the Spiritual Distress Assessment Tool in Older Hospitalized Patients. BioMed Central Geriatrics 12: 1-19. [CrossRef] [PubMed]

Montoya-Juarez, Rafael, María Paz Garcia-Caro, Concepcion Campos-Calderon, Jacqueline Schmidt-RioValle, Antonio Gomez-Chica, Celia Marti-García, and Francisco Cruz-Quintana. 2013. Psychological Responses of Terminally Ill Patients Who Are Experiencing Suffering: A Qualitative Study. International Journal of Nursing Studies 50: 53-62. [CrossRef] [PubMed]

Nascimento, Lucila Castanheira, Fabiane Cristina Santos de Oliveira, Moisés Fargnolli Moreno, and Fernanda Machado da Silva. 2010. Spiritual Care: An Essential Component of the Nurse Practice in Pediatric Oncology. Acta Paulista de Enfermagem 23: 437-40. [CrossRef]

Nilmanat, Kittikorn, Pachariya Chailungka, Temsak Phungrassami, Chantra Promnoi, Kandawasri Tulathamkit, Prachuap Noo-urai, and Sasiwimon Phattaranavig. 2015. Moving Beyond Suffering: The Experiences of Thai Persons with Advanced Cancer. Cancer Nursing 38: 224-31. [CrossRef] [PubMed]

Nyatanga, Brian. 2014. Supporting Patients in Coping with Cancer. British Journal of Community Nursing 19: 5. [CrossRef] [PubMed]

O'Donnell, Eileen, Paul D'Alton, Conor O'Malley, Finola Gill, and Áine Canny. 2013. The Distress Thermometer: A Rapid and Effective Tool for the Oncology Social Worker. International Journal of Health Care Quality Assurance 26: 353-59. [CrossRef] [PubMed]

des Ordons, Amanda Roze, Tasnim Sinuff, Henry T. Stelfox, Jane Kondejewski, and Shane Sinclair. 2018. Spiritual Distress within Inpatient Settings-A Scoping Review of Patient and Family Experiences. Journal of Pain and Symptom Management 56: 122-45. [CrossRef] [PubMed]

Perreault, Annie, and Frances Fothergill Bourbonnais. 2005. The Experience of Suffering as Lived by Women with Breast Cancer. International Journal of Palliative Nursing 11: 510-19. [CrossRef] [PubMed]

Polit, Denise F., and Cheryl Tatano Beck. 2014. Essentials of Nursing Research: Appraising Evidence for Nursing Practice, 8th ed. Philadelphia: Wolters Kluwer Health/Lippincott Williams \& Wilkins, 533p. First published 2001.

Rahnama, Mozhgan, Masoud Fallahi Khoshknab, Sadat Seyed Bagher Maddah, and Fazlollah Ahmadi. 2012. Iranian Cancer Patients' Perception of Spirituality: A Qualitative Content Analysis Study. Bio Med Central Nursing 11: 19-26. [CrossRef] [PubMed]

Rushton, Lucy. 2014. What are the Barriers to Spiritual Care in a Hospital Setting? British Journal of Nursing 23 : 370-74. [CrossRef] [PubMed]

Renz, Monika, Miriam Schütt Mao, Aurelius Omlin, Daniel Bueche, Thomas Cerny, and Florian Strasser. 2015. Spiritual Experiences of Transcendence in Patients with Advanced Cancer. American Journal of Hospice $\mathcal{E}$ Palliative Medicine 32: 178-88. [CrossRef]

Rydé, Kerstin, Maria Friedrichsen, and Peter Strang. 2007. Crying: A Force to Balance Emotions Among Cancer Patients in Palliative Home Care. Palliative and Supportive Care 5: 51-59. [CrossRef] [PubMed]

Sampaio, Rosana F., and Marisa Cotta Mancini. 2007. Estudos de Revisão Sistemática: Um Guia Para Síntese Criteriosa da Evidência Científica. Brazilian Journal of Physical Therapy 11: 83-89. [CrossRef]

Sawyer, H. 2000. Meeting the Information Needs of Cancer Patients. Professor Nurse 15: 244-47. 
Shih, Fu-Jin, Hung-Ru Lin, Meei-Ling Gau, Ching-Huey Chen, Szu-Mei Hsiao, Shaw-Nin Shih, and Shuh-Jen Sheu. 2009. Spiritual Needs of Taiwan's Older Patients with Terminal Cancer. Oncology Nursing Forum 36: 31-38. [CrossRef] [PubMed]

Shorten, Allison, and Calvin Moorley. 2014. Selecting the Sample. Evidence-Based Nursing 17: 32-33. [CrossRef] [PubMed]

Siegel, Rebecca L., Kimberly D. Miller, and Ahmedin Jemal. 2018. Cancer statistics, 2018. CA: A Cancer Journal for Clinicians 68: 7-30. [CrossRef]

Simão, Talita Prado, Erika de Cássia Lopes Chaves, and Denise Hollanda Iunes. 2015. Angústia Espiritual: A Busca Por Novas Evidências. Revista de Pesquisa: Cuidado é Fundamental Online 7: 2591-92.

Skalla, Karen A., and Betty Ferrell. 2015. Challenges in Assessing Spiritual Distress in Survivors of Cancer. Clinical Journal of Oncology Nursing 19: 99-104. [CrossRef] [PubMed]

Sutton, Jane, and Zubin Austin. 2015. Qualitative Research: Data Collection, Analysis, and Management. The Canadian Journal of Hospital Pharmacy 68: 226-31. [CrossRef] [PubMed]

Tiew, Lay Hwa, Kwee Jian Hui, Debra K. Creedy, and Moon Fai Chan. 2013. Hospice Nurses' Perspectives of Spirituality. Journal of Clinical Nursing 22: 2923-33. [CrossRef] [PubMed]

Timmins, Fiona, and Sílvia Caldeira. 2017. Assessing the Spiritual Needs of Patients. Nursing Standard 31: 47-53. [CrossRef] [PubMed]

Torre, Lindsey A., Rebecca L. Siegel, Elizabeth M. Ward, and Ahmedin Jemal. 2016. Global. Cancer Incidence and Mortality Rates and Trends-An Update. Cancer Epidemiology, Biomarkers E Prevention 25: 16-27. [CrossRef]

Villagomeza, Liwliwa R. 2005. Spiritual Distress in Adult Cancer Patients: Toward Conceptual Clarity. Holistic Nursing Practice 19: 285-94. [CrossRef] [PubMed]

Vrinten, Charlotte, Lesley M. McGregor, Małgorzata Heinrich, Christian von Wagner, Jo Waller, Jane Wardle, and Georgia B. Black. 2017. What Do people Fear About Cancer? A Systematic Review and Meta-Synthesis of Cancer Fears in the General Population. Psycho-Oncology 26: 1070-79. [CrossRef] [PubMed]

Wein, Simon. 2011. Impact of Culture on the Expression of Pain and Suffering. Journal of Pediatric Hematology/Oncology 33: S105-S107. [CrossRef] [PubMed]

WHO. 2014. World Cancer Report. Geneva: World Health Organization, International Agency for Research on Cancer, 630p.

Williams, Beverly Rosa. 2004. Dying Young, Dying Poor: A Sociological Examination of Existential Suffering Among Low-Socioeconomic Status Patients. Journal of Palliative Medicine 7: 27-37. [CrossRef] [PubMed]

Williams, Barbara J. 2012. Self-Transcendence in Stem Cell Transplantation Recipients: A Phenomenologic Inquiry. Oncology Nursing Forum 39: 41-48. [CrossRef] [PubMed]

Wilson, Keith G., Harvey Max Chochinov, Christine J. McPherson, Katerine LeMay, Pierre Allard, Srini Chary, Pierre R. Gagnon, Karen Macmillan, Marina De Luca, Fiona O'Shea, and et al. 2007. Suffering with Advanced Cancer. Journal of Clinical Oncology 25: 1691-97. [CrossRef] [PubMed]

Wilt, Joshua A., Joshua B. Grubbs, Kenneth I. Pargament, and Julie J. Exline. 2016. Religious and Spiritual Struggles, Past and Present: Relations to the Big Five and Well-Being. The International International Journal for the Psychology of Religion 27: 51-64. [CrossRef]

Yang, Hua. 2018. Coping: A concept analysis in the cancer context. TMR Integrative Nursing 2: 27-33.

(C) 2018 by the authors. Licensee MDPI, Basel, Switzerland. This article is an open access article distributed under the terms and conditions of the Creative Commons Attribution (CC BY) license (http:/ / creativecommons.org/licenses/by/4.0/). 